\author{
Andreas Lund \\ Department of Teacher Education and School Research \\ University of Oslo \\ Email: andreas.lund@ils.uio.no \\ Tone M. Eriksen \\ Department of Teacher Education and School Research \\ University of Oslo
}

\title{
Teacher Education as Transformation: Some Lessons Learned from a Center for Excellence in Education
}

\begin{abstract}
This article presents some challenges that appear to be common in the current landscape of teacher education and teacher education research. We argue that the principles of transformative agency and double stimulation (Sannino, 2014; Vygotsky, 1978) offer a conceptual framework for studying changes in teacher education and can contribute to the understanding of how we can design futureoriented study programs. We synthesize some common findings from a number of projects attempting to reconfigure teacher education, transcend epistemological dichotomies and prepare teachers for a changing world. Methodologically, we use the conceptual framework mentioned above to conduct a post hoc analysis of a series of formative interventions in teacher education. The common denominator is transcending traditional academic work in teacher education. We conclude that the reconfiguration of educational research and practice in teacher education is doable and that the examples of projects presented serve as empirical lenses and carriers of new understandings of how to transform teacher education in the knowledge society.
\end{abstract}

Key words: teacher education, transformation, agency, integration, university, school, knowledge types

\begin{abstract}
Sammendrag
Denne artikkelen presenterer noen utfordringer som synes å forekomme ofte innenfor både lcererutdanning og forskning på lcererutdanning. Vi argumenterer for at prinsipper knyttet til aktørskap i endringsprosesser (transformative agency) samt dobbel stimulering (Sannino, 2014; Vygotsky, 1978) utgjør et begrepsmessig rammeverk egnet til å undersøke endringer i lærerutdanningen, og som kan bidra til forståelsen av hvordan vi kan designe fremtidsrettede studieprogrammer. Vi syntetiserer noen funn fra et antall prosjekter der rekonfigurering av lcererutdanning står sentralt og der man har søkt å overskride epistemologiske dikotomier for å forberede vordende lcerere på en verden i endring. Metodologisk bruker vi nevnte rammeverk i en post hoc-analyse av en serie formative intervensjoner $i$ larerutdanningen. Fellesnevneren ligger $i$ a overskride tradisjonelt akademisk kunnskapsarbeid i larerutdanningen. Vår konklusjon er at transformasjon og rekonfigurering av forholdet mellom teori og praksis er mulig, og at de prosjektene vi her bruker som empiriske linser, kan fungere som bærere av nye innsikter i hvordan vi kan transformere lcererutdanningen i kunnskapssamfunnet.
\end{abstract}

Nøkkelord: lererutdanning, transformasjon, aktørskap (agency), integrasjon, universitet, skole, knunnskapsformer 


\section{Introduction: Winds of change}

The interest in teacher education from policy makers as well as teacher educators and researchers has rarely been greater than at present. Teachers work in increasingly complex learning environments characterized by multicultural and technology-rich dimensions, where a research-based approach to the profession is needed to work from a solid knowledge base. In Norway, future schooling is also likely to be influenced by the Ludvigsen committee's reports, which point to the need for more emphasis on in-depth learning, progression, self-regulation, social and emotional competences, and $21^{\text {st }}$ century skills (Ludvigsen-utvalget, 2014, 2015). Such skills cover learning skills, literacy skills, and life skills (e.g., critical thinking, creative thinking, collaborating, information literacy, technology literacy, flexibility, and initiative). The committee also points to the fact that all this takes place in a veritable explosion of information and knowledge. Consequently, the implications and challenges for teacher education and the teaching profession are quite daunting. In what could be seen as a response, Norway will, beginning in 2017, introduce five-year master's programs as the backbone of teacher education.

Against this backdrop, ProTed-Norway's first center for excellence in education-works to achieve excellent and innovative teacher education in integrated study programs. This involves coping with complexity and transformation. Thus, the committee that decided to situate the center in the midst of the collaborative work between the University of Oslo and Norway's Arctic University in Tromsø, stated that ProTed should "serve as a structuring space for systematic experiments in teacher education programs that integrate a strong research base and tight collaboration between the practice field and education based on a deep interplay between profession-oriented and scientific components" (NOKUT, 2011, p. 5, our translation). Thus, ProTed can be said to serve as a developmental unit at the two universities.

In this paper, we therefore adopt a transformative perspective (Ellis \& McNicholl, 2015; Vestøl \& Lund, in press) on teacher education and teacher educators' professional development. Our aim is to contribute to an understanding of how, when facing deep challenges, we can develop, achieve, and sustain integrated and coherent study designs for master's level teacher education (Vestøl, Jakhelln, \& Lund, 2015). This involves coping with uncertainty (Edwards, Gilroy, \& Hartley, 2002) as well as instigating productive change and transformation.

By juxtaposing the mandate of the center, the introduction of five-year master's programs as the prime teacher education model in Norway, and the need for integrated, coherent, and future-oriented programs, we discuss some challenges and lessons learned in ProTed's first four years of existence. Many of the practices instigated by ProTed have originated at and traveled between the 
two universities. Thus, our approach is framed as an exploratory discussion of numerous activities at both universities through three empirical lenses:

1. The relationship between the scientific disciplines and the school subjects. Both are socio-historic constructions (i.e., they are both subject to policy making, economic interests, and ideology). But scientific disciplines are also driven by cutting-edge research and have rapid turnover rates for what is considered valid knowledge. School subjects should ideally reflect such current insights, but they have, to a greater extent, been subject to political interventions (at least in Norway) as well as to frequent curriculum development by teachers and teacher educators. Student teachers need to be familiar with such knowledge logics or epistemologies.

2. New types of partnerships between universities and schools and how this involves participants from diverse contexts and positions. The result is that teacher education needs to approach relations between education on campus and in schools as a particular type of co-configured work (i.e., a type of developmental work that relies on mutual exchange of expertise).

3. Professional digital competence in teacher education and how such competence cuts through epistemological assumptions in the learning sciences, as well as how such competence requires a deep understanding of the characteristics of separate knowledge domains.

We adopt an activity theoretical framework (Engeström, Miettinen, \& Punamäki, 1999; Sannino, Daniels, \& Gutiérrez, 2009), where sustained transformation of practices, collective object orientation, relational expertise, and co-configuration of work are vital constructs. Methodologically, we draw on secondary data such as project outcomes, exam designs, and relevant documents. We conclude with a discussion of designs for transformation and future-oriented practices and research agendas. We argue that the work at the ProTed center shows that implementation of such insights is a much needed and realistic endeavor for teacher education institutions.

\section{Selected review: Research traditions and contexts}

Since this text covers a lot of ground and issues that in themselves warrant separate and detailed literature reviews, we limit this section to only a few carefully selected international studies that give a snapshot of research on teacher education. In addition, some relevant studies will be referred to in the empirical section and the discussion of the three thematic issues.

Early in 2015, Marilyn Cochran-Smith and colleagues mapped the landscape of research on teacher education by reviewing more than 1,500 studies published 
between 2000 and 2012 from diverse parts of the world, including Norway (Cochran-Smith \& Villegas, 2015; Cochran-Smith et al., 2015). From a position where research on teacher education is seen as a "historically situated social practice" (Cochran-Smith \& Villegas, 2015, p. 7), they identified three major research programs: (1) research on teacher preparation for accountability, effectiveness, and policies; (2) research on preparation for the knowledge society; and (3) research on teacher preparation for diversity and equity. These are clusters with numerous subcategories involved. On the whole, the authors found "that sociocultural perspectives have been widely taken up by teacher education researchers" (Cochran-Smith et al., 2015, p. 113), particularly concerning the second category. We argue that the present paper primarily belongs to the second category, not least because this category has strong links to the learning sciences and changing conceptions of how people learn and construct new knowledge; nevertheless, the other two are not excluded.

The articles did not review the various methodological approaches in the studies (although they offered a brief historical overview), but the authors stated that their review "is deliberately inclusive of multiple - sometimes competing research approaches and agendas," adding up to "a 'sprawling' field of research" (Cochran-Smith \& Villegas, 2015, p. 8). This lack of methodological consensus is in itself interesting, as it indicates a potentially productive diversity as well as potentially new spaces for methodological approaches. It is also relevant to note that for the second category (research on teacher preparation for the knowledge society) the authors emphasized the need to study teacher preparation for coping with and initiating change. Of further relevance to the present paper is the need for "studies that investigated how preparation influenced the candidates' practice" and the observation that "few studies connected aspects of teacher preparation/certification to students' learning” (Cochran-Smith et al., 2015, p. 117). The authors pointed to research questions developed jointly by school and university as a way of establishing or strengthening such connections.

A complementary study to that of Cochran-Smith and colleagues, but with a specific focus on methodological approaches, was done by Menter et al. (2010). These authors reviewed 446 studies about teacher education in the United Kingdom published between 2000 and 2008, thus coinciding with the mapping undertaken by Cochran-Smith et al. Menter et al. summarized their classification of research methods in the United Kingdom in a table dominated by qualitative, small-scale studies based on reflection and interviews. Although the United Kingdom may differ from other countries regarding teacher education programs and policies (as duly noted by the authors), we recognize observations such as "teacher education research appears to be a relatively under-developed area, without a strong theoretical or methodological tradition” (p. 124).

From policy levels as well as researchers, the response has been to require research that can demonstrate "what works" and teacher education accountability often embedded in effect sizes or mathematical tags that amount to audits. 
However, such research, even at its best, is restricted by being fundamentally retrospective and not focusing on the many challenges that emerge when the turnover rate of valid knowledge increases rapidly, when knowing and learning (and teaching) are distributed over multiple agents and artifacts, and when schools and universities (or university colleges) form new partnerships where theory and practice are considered two mutually constitutive knowledge forms of professional development. As neither of the overviews offered by CochranSmith or Menter pointed to approaches that aim to capture how student teachers (or teachers) face complexity, transformation, and potential expansion, we demonstrate and discuss such issues in the following.

Current trends in research and practice show that teacher education needs to be future oriented, innovative, expansive, research informed, and relevant in ways that may not be found in existing practices. This has brought about a wide variety of reforms and approaches. As Ellis and McNicholl (2015) observed, "Around the world, ITE [initial teacher education] continues to be in a state of almost continual reform, even crisis" (p. 6). The authors pointed to two very different responses to such a crisis. First, they discussed what they referred to as the global education reform movement (GERM). At the heart of this movement is accountability in the tradition of the "hard" sciences, with emphasis on controlled variables, measurement, effects and outcomes, and statistical benchmarks. This does not always go well with the tradition in higher education, where teacher education is perceived as a context for reflection and personal and social growth and where the formative aspect of education, Bildung, is cultivated. However, Ellis and McNicholl issued a warning that merely defending this latter position is insufficient and counterproductive. Instead, they offered a third, transformative agenda, driven by educational questions and not by positions on policies. This does not amount to a recipe or model for teacher education but opens up a bold revitalizing and, as the authors suggested in the subtitle of their book, "reconfiguring the academic work".

It is to this third position that we intend to contribute, using some of ProTed's work as empirical carriers of reconfiguration. The questions guiding our exploration and discussion are as follows:

- What are some of the challenges and potentials in reconfiguring teacher education?

- What resources and infrastructures may be developed and how?

To respond to these questions, we first need to briefly discuss our conceptual framework before we present three areas where ProTed has worked systematically to build a knowledge base as well as put such knowledge to work in our teacher education programs. 


\section{A conceptual framework for transformation}

From a Vygotskyan and cultural-historical activity theory (CHAT) perspective (Engeström et al., 1999; Sannino et al., 2009; Vygotsky, 1978), we approach expansive, transformational, and future-oriented teacher education. The reasons for using CHAT are as follows: it is a theory of transformation and development, it presupposes a collective motive or object to be realized and/or expanded, it places cultural resources (material, social, linguistic, and semiotic) at the heart of this endeavor, and it links the mind to social and institutional contexts. Thus, the unit of analysis is the collaborative activities enacted in a particular setting. CHAT also emphasizes the historical roots of cultural development and thus avoids becoming a model for mere management. We argue that this perspective has explanatory power when examining transformation in institutions where individual and systemic levels are juxtaposed and intertwined and where traditions and cultural values are nurtured as well as challenged. Teacher education is one emblematic example. For instance, Ellis, Edwards, and Smagorinsky (2010) used CHAT as a theoretical and methodological lens through which to conceptualize teacher education as something much more multifaceted and mutually constituted by its many agents and their uses of cultural tools than viewing classroom teaching and learning as output from specific programs. However, CHAT has sometimes been criticized for placing too much emphasis on the organizational and collective level and less on how individuals, singularly or collaboratively, exercise agency to realize an object or bring an object to fruition. Thus, we turn to recent work in this field (Lund \& Rasmussen, 2008; Sannino, 2014; Vestøl \& Lund, in press) that resurrects two Vygotskyan principles for studying and enacting volitional and transformative action: the principle of transformative agency and the principle of double stimulation-principles that we argue have explanatory power when studying, putting into operation, and sustaining phenomena that are currently evolving. Both are briefly explained in the following.

First, we use the principle of transformative agency (Sannino, 2014; Vestøl \& Lund, in press) to examine how agents cope with situations that require breaking out of or deciding between multiple alternatives, double binds, dilemmas, or situations that are not sustainable, or how they renew practices that have ceased to be productive. Thus, transformative agency involves acknowledging problems while mustering the resources that can solve them. Such resources can be material and financial as well as conceptual, linguistic, and social. While transformational agency originally stems from the social psychology tradition of Vygotsky, it has increasingly been applied to systemic levels and organizational change.

Second, we adopt the Vygotskyan principle of double stimulation (Ellis, 2010; Engeström, 2007; Lund \& Rasmussen, 2008) to further operationalize transformative agency. The situation requiring change (as in the above para- 
graph) amounts to the first stimulus (S1). The available resources that agents engage with or co-configure for particular goals amount to the second stimulus (S2). It is important to note that S2 consists of a series of available cultural resources to (ideally) be productively employed by the agent(s). This act of mediated volitional action stands in contrast to behavioristic models where the agent reacts automatically, by stimulated response, and not by considering options and strategies. But cultural resources also come with intentions or inscriptions that sometimes suggest a particular use and sometimes interfere with or disrupt human action (Latour, 1999; Lund \& Rasmussen, 2008; Shaffer \& Clinton, 2006). Examples are cars that will not start until seat belts are fastened, computer applications intended for collaboration, or signs or linguistic cues that suggest directions to take or where not to go. In sum, the principle of double stimulation makes the relationships between agents, challenges, and available resources visible along with the purposes such relationships serve (see the empirical section in this paper).

As we indicated in the introduction, deep complexity characterizes teacher education in an increasingly multicultural and technology-rich world. To design relevant and valid study programs, we need to know what is involved, what is at stake, and how we can design future-oriented activities, courses, and programs in a systematic way. We argue that the principles of transformative agency and double stimulation offer a conceptual framework for doing this, and we put these principles to use when we turn to the empirical section below. However, we first discuss our methodological approach.

\section{Methodology: Formative interventions and post hoc analysis}

Over its first four years of existence, ProTed has instigated, supported, and been involved in approximately 30 different projects on campus and in a series of projects involving university schools. Many of these are presented in detail and discussed in a comprehensive anthology on the work done by ProTed in its first three years of existence (Rindal, Lund, \& Jakhelln, 2015), but not from a specifically transformative perspective. The common denominator of the ProTed projects is that they add to the knowledge base and enactment of integrated teacher education programs. From this range of projects, we selected three cases (not used as in "case study", but more as a term to cover a cluster of related activities) that were used as empirical lenses through which we examined the transformation of teacher education practices. The selection of empirical lenses corresponds with three of ProTed's main developmental areas: teaching in the disciplines, university schools, and digital learning environments and professional practice. Thus, the cases were not developed for the purpose of the present study but were derived from our existing project portfolio. We read the cases from a retrospective perspective to identify the aspects within the cases that 
serve as carriers of the principles we focus on in this paper. The aspects identified may serve as examples of important and necessary trajectories of change to be examined in teacher education. Although some previous research has focused on transformation, reconfiguration, or expansion in teacher education (Ellis, 2011; Ellis \& McNicholl, 2015), such studies have not, to the best of our knowledge, been applied to specific activities or dimensions that make up a transformed program. However, Ellis' (2011) study addressed teachers' (and teacher educators') capacity to transform, combine, and create something new in their practices-“professional creativity” (p. 182).

The three cases add up to what may be termed a broad, formative intervention approach (Engeström, 2011) but are analyzed post hoc. Formative interventions acknowledge the agency (and potential resistance) that agents display when collaboratively engaged in change processes. Post hoc analysis is suitable for finding patterns and/or relationships between agents or activities that would otherwise remain undetected when analyzed in situ. Often, post hoc analysis involves statistical sampling. However, in the present paper, our post hoc analysis is mirrored against a conceptual framework (outlined above) to detect patterns and common denominators and afford theoretical generalization. It follows that our data is not gleaned from first-hand systematic observation, recorded discourse, or interactions but might be termed secondary data in the sense that it is collected by others and found in documents, agreements, proposals, exam papers, and program descriptions. One obvious limitation is that we do not get to follow agents engaged in the processes where they align S2 with $\mathrm{S} 1$ to construct new practices or infrastructures. This is beyond the scope of the present paper but can be examined elsewhere in situations where student teachers as well as teacher educators confront challenges (Vestøl \& Lund, in press).

The empirical section is structured around three methodological principles:

1. It identifies challenges, problems, need states, etc. (S1)

2. It identifies available resources (S2) to suspend, solve, manage, or transform S1.

3. It identifies the results that materialized/are materializing in the cases.

Together, these principles inform the ensuing discussion on expanding the object of teacher education by transformational agency.

\section{Empirical lenses}

\section{Scientific disciplines and school subjects}

Questions about what types of knowledge teachers need for teaching have accompanied the development of the profession for decades. Responses have been particularly inspired by Lee Shulman's $(1986,1987)$ seminal work on how 
teachers translate their disciplinary knowledge into classroom practices and by Pamela Grossman's (1990) definition of pedagogical content knowledge as consisting of knowledge of students' conceptions of content, curriculum, teaching strategies, and purposes for teaching. This Anglo-American tradition is similar, but not identical to, the European notion of didactics (and subject didactics). However, the latter places emphasis not only on what you should know but also on what you should become (e.g., in the Bildung tradition; Gundem, 1998; Hamilton, 1999; Klafki, 1998). These are all still valid issues, but others have been added over the years, especially because of a veritable knowledge explosion in science, in product development, and in our daily lives. The turnover rate of what counts as current knowledge is increasing to the extent that most information in certain domains is less than 15 years old and the sheer amount of documented knowledge in certain sciences doubles every eight years (Lødrup \& Haugli, 2014). Add to this the conclusions from the committee producing a knowledge basis for the school of the future in Norway and implications for a redesigned curriculum with more emphasis on deep learning and progression (Ludvigsen-utvalget, 2014, 2015), and we see how teachers' disciplinary knowledge is vital to professional practice. Such emphasis on disciplinary expertise is quite common in scholarly literature (see e.g., Schempp, Manross, Tan, \& Fincher, 1998, who also cite a number of studies).

Consequently, there is a great responsibility for teachers to keep up with the research frontiers in their knowledge domains. This is also why we in ProTed have nurtured the motto that good disciplinary education is good teacher education. However, teachers are not historians but teachers of history; they are not scientists but teachers of science; they are not linguists but teachers of languages, and so on. While the scientific disciplines in higher education will always be constrained as well as driven by ideologies and economic imperatives, they are also closely connected to pushing the research frontiers. School subjects are also social, historical, and cultural constructions, but to a greater extent, they are reductions of the scientific disciplines in accordance with educational and national policies. The social norms of a specific discipline can be emphasized or rejected (e.g., in issues such as sustainable development or multicultural societies). These are epistemological considerations.

So, how can the scientific discipline speak to or translate into the practices that young learners engage in? Or, to rephrase, how can teachers make complex and cutting-edge knowledge accessible in classrooms? How important is the teachers' disciplinary knowledge and the scientific discourse that serves to convey such knowledge (see also Knain, 2015)? These are the questions that amount to a need state for drawing on different sources of knowledge and concepts to develop innovative and engaging approaches to subject didactics. Student teachers live with the tensions found between loyalty to a university's academic tradition and the requirements found in the profession. This is, in short, the first stimulus, S1. In the following, we turn to a number of ProTed projects 
that, in various ways, have sought to respond to such a challenging S1 by drawing on available cultural resources (i.e., a series of stimuli or S2).

For example, the course Math, School, and Culture (MA level) prepares student teachers to explain mathematical problems orally in a way that their future pupils can relate to. Spoken proficiency in math teaching is thus used as an integrative element. A related project is the use of drama pedagogical methods, also in math; such methods make it possible to expand on the traditional IRF structure (teacher initiates, learner responds, teacher feeds back) by allocating specific roles to participants. Similar methods are used in a project where a collaboration between the academic disciplines of Norwegian, English, and drama produces exercises where student teachers are challenged to enact roles to explore language attitudes in a multicultural and plurilinguistic society (Sollid \& Rindal, 2015). In the academic discipline of history, students systematically engage in the online publication of articles based on their MA theses and in writing for newspapers and producing podcasts. Hence, the course specifically aims to teach students to communicate history and not just know it. Finally, the ReleQuant project bridges research and practice by developing networked learning resources and communicative strategies for making relativity theory and quantum physics relevant in classrooms. Through systematic classroom observations, video and audio recordings, pupils' written material, and interviews with pupils and teachers, student teachers engage in a research-based approach together with researchers and school teachers to find out what works in classrooms (for a detailed presentation, see Henriksen, Angell, \& Tellefsen, 2015).

One common denominator in the projects outlined above is that they have been initiated by disciplinary communities and supported by ProTed. A second common denominator is that they aim at integrating the scientific discipline and the school subject, as well as integrating knowledge produced on campus with knowledge produced in schools. A third common denominator is the shift toward more student active types of learning. These three S2 principles build on co-configuration to reconfigure a course or components of a course. Although participants may represent different fields of expertise and thus have different motives or objects, they engage collectively in a type of knowledge work across boundaries. A fourth stimulus is the discourse used to communicate disciplinary issues, both the scientific concepts and everyday vernacular. Finally, digital technologies are put to use where they serve to ease collaboration and afford greater visibility of practices. Thus, the projects show how a series of available second stimuli-social, linguistic, and material—become visible and how agents select and prioritize to achieve results. In turn, these results are operationalized in the redesign of courses and program components. In ProTed, this is a specific developmental area in itself (see Rindal et al., 2015) but is not pursued in this paper. 
Through this brief overview of projects at the juxtaposition of academic disciplines and school subjects, we see how different types of knowledge are put to work and how different arenas for professional development are activated through transformative agency enacted across contexts. This interplay between arenas also forms the basis for the following section.

\section{Partnerships and university schools}

Beyond the transformation from scientific discipline knowledge to school subject knowledge reflected in the discussion above, teacher education programs have generally been accused of not resolving their relationship with partner schools, neither through educational research nor through models of student teachers' practice periods (Ellis \& McNicholl, 2015). Rejecting a dichotomy between classroom knowledge and theoretical knowledge, Ellis and McNicholl suggested rethinking the way educational research and the professional field interact (this is also emphasized in Ludvigsen, 2015). This has implications not only for the design of professional learning in teacher education, but also for how educational research questions are defined and how a shared discourse on educational practices can emerge. As El Kadri and Roth (2015) showed, multiple studies have confirmed the need for constructive alignment between theoretical and practice-based knowledge. However, the transformative potential of practice periods is rarely conceptualized. El Kadri and Roth described the potential of developing practice as a locus of multileveled transformation for all parties involved, not just students, where collective agency potentially resolves contradictions and ambiguities between academic and practical traditions of knowledge development.

Recognizing the need for rethinking the way research and practice interact, teacher education programs worldwide are developing novel partnership models. In a review of research on partnership models, the Norwegian Knowledge Center for Education identified common themes and findings (Lillejord \& Børte, 2014). Research shows that successful partnership requires symmetry and equal opportunities between participants, as well as common objects and mutual ownership of and commitment to collaboration. Furthermore, the complexity and resources needed in such partnerships must be taken into account.

The review concluded that there is extensive research identifying challenges in and conditions for constructive partnerships, but there are fewer studies unpacking the transformation that takes place when different representations of knowledge interact in what is frequently described as a "third space". As an extension of the traditional triangular model consisting of the student, the supervisor from university, and the mentor in school ${ }^{\mathrm{i}}$, a "third space" model (as in Fig. 1) places the student teacher at the center of interacting activity systems where constructive interaction between academic knowledge and practice-based knowledge in teacher education emerges. As such, it is similar to collaborative partnerships (Furlong, Barton, Miles, Whiting, \& Whitty, 2000) in which 
universities and schools form a symmetric and dialectic relationship based on reciprocal acknowledgment as well as questioning of epistemologies and knowledge types. However, this is a very demanding and resource-intensive partnership. Consequently, ProTed has so far concentrated on identifying and launching specific activities (see the three examples below). Also, we do not experience a friction-free or harmonious zone; agents from both arenas need to adjust and negotiate positions and acknowledge the knowledge practices involved. But by placing the student teacher at the center of the partnership, the locus of attention is on the student's development. The challenge of operationalizing such a model (Fig. 1) can be seen as the first stimulus, S1, within the partnership theme.

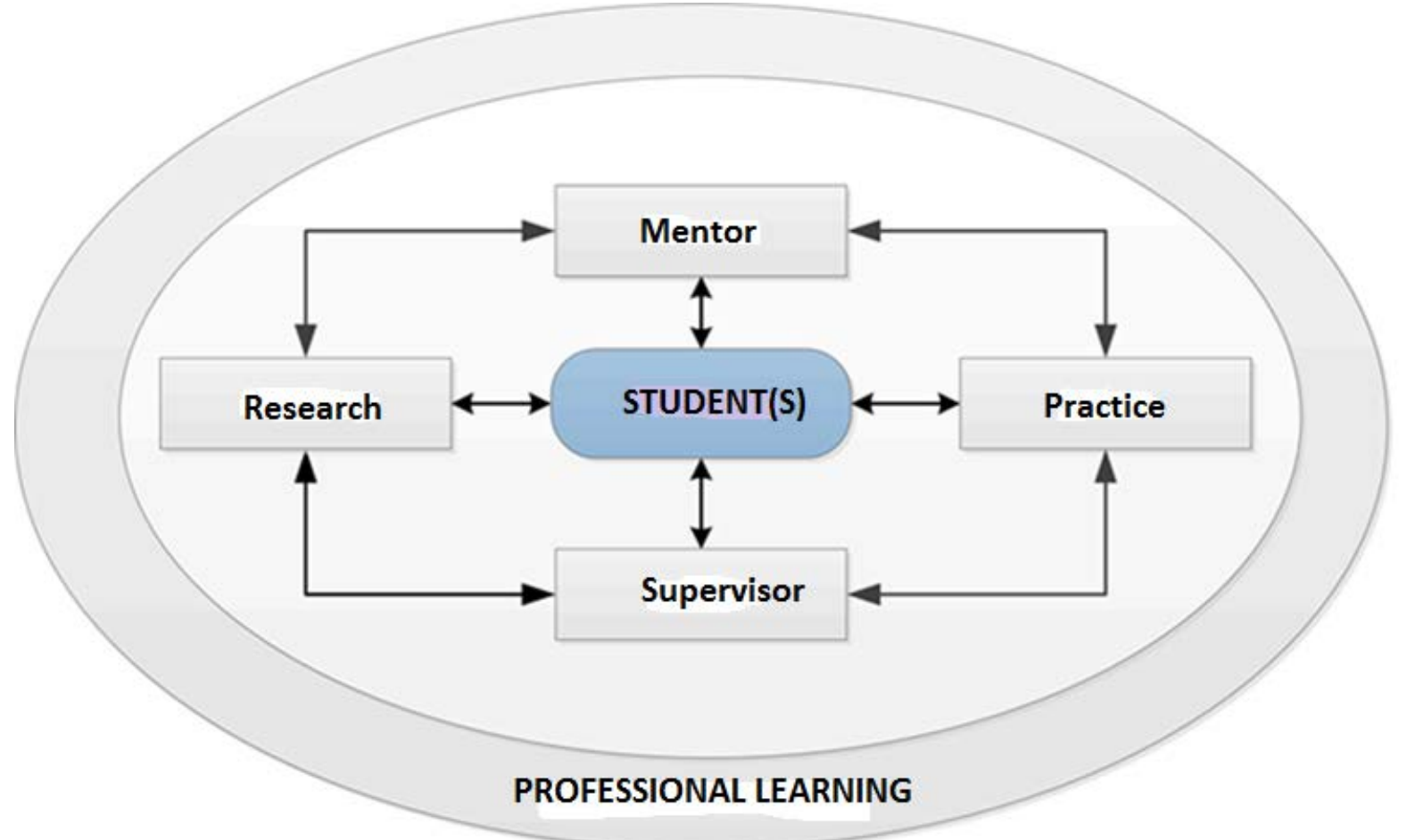

Figure 1. Student-centered partnership (from Lillejord \& Børte, 2014, p. 22, our translation)

Partnerships with schools are an important cornerstone in ProTed's work to promote excellent teacher education. Recognizing the need to create dynamic, symmetrical, and sustainable collaboration with schools, we have established the concept of university schools (Eriksen, Hunskaar, \& Hyldmo, 2014; Rørnes, 2015). These are schools that apply for status as university schools and are selected among all the schools that provide clinical practice in the teacher education programs. Collaboration between the university schools and the universities is regulated in a mutually binding agreement in which both parties take responsibility to integrate the experiences that students are exposed to on campus with those that take place in the schools. There are three main objectives in the agreement: developing practices in teacher education on campus, developing quality and integration in clinical practice, and developing collaboration in $\mathrm{R} \& \mathrm{D}$ projects that are mutually beneficial for schools and universities. In the 
following, we briefly give three examples of how we have sought to operationalize some of these dimensions.

First, we have developed arenas for integration between different types of knowledge: academic and experience based. The former is often of a more strategic type, while the latter is often required to be applied in situ. Thus, there are two different logics involved. Both types are mutually constitutive of professional development and cannot be dichotomized. One such arena that has been cultivated for some time is the dialogue seminars. These are set up as a space where student teachers meet with supervisors from universities as well as mentors and teachers in schools. The aim is to have a multivoiced approach to issues that students encounter in their education (e.g., specific situations they experience in their practice, discipline-specific challenges, and links to scholarly literature) and illuminate these from several angles where diverse knowledge forms are put into play. The seminars function as an innovative tool for a shared conception of what the many aspects of teacher education entail for the students, consequently functioning as a development space for the other participants as well.

Similarly, integrated weeks involve university schools at all levels to familiarize student teachers with the school's educational ecology. Vital to the integrated weeks is the collaboration between pedagogues and subject didactics experts. From a situation where content and reading lists in pedagogy and subject didactics were overlapping or mismatched, integrated weeks have balanced the two disciplines and made them serve shared objectives in education (for a detailed discussion, see Brevik \& Rindal, 2015).

Finally, seed money has been allocated to joint research projects between university and university schools. This is a two-way initiative; either the teacher education department can initiate a project with a school to foster a researchbased approach to a certain practice or phenomenon, or the initiative can come from the schools but with the same objectives. However, this is not a project for organizational development; the benefit for teacher education must be obvious to generate funding. The seed money is a recent effort and is still in the process of being implemented. But funding has been allocated to projects where, for instance, one school engages in multidisciplinary approaches, another school's teachers and researchers engage in analyzing statistical data from large-scale international projects to better understand them, and schools engage in writing in and across school subjects.

At the heart of co-configuring and reconfiguring partnerships, we see a series of conceptual, organizational, and financial stimuli. The university schools project shows great promise and has inspired other institutions in Norway to appropriate the concept and translate it to local contexts. One important reason may be that from perceiving their role as recipients of student teachers, university schools now recognize and appreciate their role as teacher educators, equal to but still different from the university (Eriksen et al., 2014). 


\section{Professional digital competence}

Professional digital competence (PDC) entails a double challenge for teachers: While they, like other professionals such as engineers, lawyers, or nurses, need to be proficient in using digital technologies (ICT) for certain professional tasks, their main challenge is to foster productive and relevant use of ICT among their pupils. However, recent reports and studies have suggested that teacher education has prepared teachers only to a little extent for this. What adds up to an S1 in this field can be summarized as follows (see Lund, Furberg, Bakken, \& Engelien, 2014 for an extended discussion).

There is a weak relationship between the integration of ICT in schools and the integration of ICT in Norwegian teacher education programs, and newly qualified teachers find that they have to educate themselves. The objectives of developing PDC among student teachers are not firmly anchored in teacher education programs, there is no coherent approach, and competence among teacher education staff varies considerably. In institutions where such competence has been developed, it is often vulnerable and depends on individuals. Thus, there are few examples to show that teacher education programs formulate or operationalize how PDC can be related to what good teacher education actually is.

ProTed's response has been partly to conceptualize what PDC entails in teacher education and partly to operationalize such conceptualization in the integrated teacher program and a new type of exams. Therefore, there is a series of activated S2 at the conceptual as well as technological and institutional levels.

Conceptually, we have advocated a view of digital technologies that removes them from metaphors of tools and instruments, since such metaphors carry notions of instrumentalism. They also risk reducing digital technologies to a role where they economize or speed up existing practices and consequently open up a perspective where their use value is restricted to measurable learning outcomes. In ProTed, we conceptualize digital technologies as cultural artifacts that have the potential to transcend and transform cultures and cultural practices. In knowledge practices, this is evident in the way digital technologies open up unlimited access to information stored in collective memories such as archives, and in how cognition becomes increasingly distributed across human agents and the artifacts or cultural resources we use (e.g., pocket calculators, memory sticks, GPS systems). Digital technologies also afford a number of multimodal forms of knowledge representations. There are epistemological implications: how we come to knowledge as well as how knowledge is represented. Models, simulations, and new communicative ecologies as networked technologies suspend constraints in time and space and open up new communicative genres by linking minds and hands. This means that technologies do not only have a generic impact on how we learn but also have specific implications for how we teach in various subjects.

Conceptualizing digital technologies as artifacts with transformative potential gives us a theoretically validated foundation for transforming existing 
practices or introducing new ones. The following is a selective, brief list of ProTed practices:

- Assessing student teachers' practice. Such assessment is mediated by tablets and video recordings and involves fellow students, supervisors from the university, and mentors in schools. Thus, ephemeral "teachable moments" are made visible and subject to collaborative discussions. At the same time, the arrangement opens up increased agency from the students (for a video presentation, see https://youtu.be/IYsnvwM3zDc).

- Flipped classroom model for teachers who are enrolled in our part-time program, where teachers are distributed among many schools. The flipped approach is mediated by a digital platform that affords the use of structured and shared learning resources (e.g., video sequences) designed to generate teaching-oriented discussions. In addition to freeing up time for student activities, the model and the platform compensate for the lack of a co-located presence.

- Modules that develop PDC through design activities. Student teachers are engaged in designing technology-rich learning environments and trajectories (Lund \& Hauge, 2011) where they integrate disciplinary and professional expertise as well as their experiences from practice periods. Designs are enacted during practice periods and experiences are shared.

- A “digital exam" that differs from traditional exams in many respects. Students know the task from the beginning of the semester but will have to relate it to a digital video with a specific classroom situation. Students may collaborate; they may sit at home or meet on campus, and all resources (e.g., literature, Internet) are available. The finished exam paper is submitted via a remote desktop solution and is immediately available for evaluation (see Lund \& Engelien, 2015 for an extended discussion).

Thus, to respond to an S1 of failing to foster PDC in teacher education, we see how a series of S2 involves the interplay between conceptual, organizational, institutional, and technological levels.

\section{Discussion: S1 and S2 at an aggregated level}

When we go from analyzing the three areas separately to analyzing them at an aggregated level, we see how the relations between S1 and S2 and the various second stimuli manifest. Table 1 gives a condensed picture: 
Table 1

Overview of S1 and S2 in the cases discussed

\begin{tabular}{|c|c|c|}
\hline $\begin{array}{l}\text { S1: Challenge, problem, } \\
\text { dilemma, or need state }\end{array}$ & $\begin{array}{l}\text { S2: Available resources to } \\
\text { suspend, solve, manage, or } \\
\text { transform S1 }\end{array}$ & $\begin{array}{l}\text { Results } \\
\text { ( } \neq \text { "finished products") }\end{array}$ \\
\hline $\begin{array}{l}\text { How to link the research- } \\
\text { driven scientific discipline to } \\
\text { the school subject }\end{array}$ & $\begin{array}{l}\text { Scientific discourse } \\
\text { Everyday vernacular } \\
\text { Collaboration across domains } \\
\text { Exploring and fostering more } \\
\text { active student roles } \\
\text { Digital technologies }\end{array}$ & $\begin{array}{l}\text { University courses with more } \\
\text { school relevance } \\
\text { Innovative teaching practices }\end{array}$ \\
\hline $\begin{array}{l}\text { How to turn the campus and } \\
\text { the school into two mutually } \\
\text { constitutive arenas for } \\
\text { professional development }\end{array}$ & $\begin{array}{l}\text { University schools } \\
\text { Dialogue seminars } \\
\text { Integrated weeks } \\
\text { Seed money }\end{array}$ & $\begin{array}{l}\text { Schools as teacher educators } \\
\text { Joint R\&D projects } \\
\text { More symmetry in power } \\
\text { relations }\end{array}$ \\
\hline $\begin{array}{l}\text { How to foster PDC among } \\
\text { student teachers }\end{array}$ & $\begin{array}{l}\text { Conceptualizing ICT } \\
\text { Tablet-mediated supervision } \\
\text { Flipped classroom } \\
\text { Design principles operationalized } \\
\text { in modules and seminars } \\
\text { Integrated exam designs }\end{array}$ & $\begin{array}{l}\text { PDC integrated in five-year } \\
\text { master's program } \\
\text { Redesign of part-time program } \\
\text { Student teachers' exam papers } \\
\text { responding to new tasks }\end{array}$ \\
\hline
\end{tabular}

Kennedy (1990, p. 14) observed that educational researchers "tend to focus on pedagogy while leaving issues of content to their disciplinary colleagues" and added that "most of their findings about pedagogical practices are valid only for the teaching of routine skills". In a knowledge society where different knowledge types and logics convene and new competences are required, this is an untenable position. Teacher education as well as research on and about teacher education has come a long way since this observation was made. The more we learn about teacher education, the more we see how an integrative and futureoriented education is essential. Moreover, we are starting to see what this entails from all parties involved and how we need to build supporting structures.

By moving across a cluster of projects, we have shown how demanding challenges (S1) can be responded to by mustering a series of resources (S2) at different levels. The links between S1 and S2 are the keys to developing relevant and sustainable teacher education. Two such links emerge as particularly salient. First, the match between S1 and S2 has to be absolute so as not to merely produce "stunts" instead of sustainable and productive change. This is what Vygotsky (1986) referred to as the principle of double stimulation. Second, when a series of S2 emerge or are made available, agents (teacher educators in academia and schools, student teachers, and leadership) need to exercise transformative agency based on professional expertise. In all the examples discussed above, a substantial amount of such agency was demonstrated. However, agency will have to be supported by contextual, particularly institutional, stimuli as well.

In the various transformative efforts discussed in this paper, we have come across conceptual, organizational, institutional, financial, and technological 
stimuli. They may appear with different importance or weight in the various projects. However, it is always the amalgamation of these stimuli that makes a transformative effort strong enough to become sustainable. In sum, we also see how reconfiguring teacher education for the knowledge society touches upon epistemological issues and thus needs to be aligned with theoretical advancement in the learning sciences.

\section{Conclusion: It is doable}

Our first research question asked what some of the challenges and potentials are when reconfiguring teacher education. This paper sought to demonstrate how teacher education faces challenges from the knowledge society and how we can respond. To go beyond a mere series of examples, we established two principles for bringing about research-informed and sustainable change: double stimulation and transformative agency. These principles were then applied to the second research question about what, and how, resources and infrastructures may be developed.

The examples of developmental work and post hoc analysis of the cases presented show that transcending traditional organizational, cultural, and disciplinary boundaries to transform teacher education is doable. However, there are substantial challenges that go way beyond organizational measures and involve epistemological reorientation as well as an awareness of policy issues. Although the transformation is complex and takes place in small steps, the work conducted by ProTed makes gradual contributions to teacher education programs that develop professional teachers who are prepared to teach in rapidly changing knowledge societies. This brings us to a concluding point: Transformative agency is linked to identifying priorities and levels of ambition, not so much to a total makeover of the five-year master's program, and to a state of flux where permanent transformation becomes the norm. We are currently experiencing an increasing turnover rate of what counts as valid knowledge, technologies that deeply affect traditional epistemologies and learning environments, and a search for new partnerships between universities and schools. In such a situation, we will need student teachers who are not merely enculturated into existing practices, but who are also professionally creative (Ellis, 2011) and who can design new practices with ecological validity for a changing world. 


\section{References}

Brevik, L. M. \& Rindal, U. (2015). Fagdidaktisk makeover. Om utviklingen av et integrert studiedesign i engelsk didaktikk i lærerutdanningen [Subject didactic makeover. On the development of integrated study design in English didactics for teacher education]. In U. Rindal, A. Lund, \& R. Jakhelln (Eds.), Veier til fremragende læererutdanning [Roads to excellence in teacher education] (pp. 185-195). Oslo: Universitetsforlaget.

Cochran-Smith, M. \& Villegas, A. M. (2015). Framing teacher education research: An overview of the field, part 1. Journal of Teacher Education, 66(1), 7-20. doi: http://dx.doi.org/10.1177/0022487114549072

Cochran-Smith, M., Villegas, A. M., Abrams, L., Chavez-Moreno, L., Mills, T., \& Stern, R. (2015). Critiquing teacher education research: An overview of the field, part 2. Journal of Teacher Education, 66(2), 109-121. doi: http://dx.doi.org/10.1177/0022487114558268

Edwards, A., Gilroy, P., \& Hartley, D. (2002). Rethinking teacher education: Collaborative responses to uncertainty. London: RoutledgeFalmer.

El Kadri, M. S. \& Roth, W.-M. (2015). The teaching practicum as a locus of multi-leveled, school-based transformation. Teaching Education, 26(1), 17-37. doi: http://dx.doi.org/10.1080/10476210.2014.997700

Ellis, V. (2010). Studying the process of change. The double stimulation strategy in teacher education research. In V. Ellis, A. Edwards, \& P. Smagorinsky (Eds.), Cultural-historical perspectives on teacher education and development (pp. 95-114). Oxon, UK: Routledge.

Ellis, V. (2011). Re-energising professional creativity from a CHAT perspective: Seeing knowledge and history in practice. Mind, Culture and Activity, 18(2), 181-193.

Ellis, V., Edwards, A., \& Smagorinsky, P. (Eds.). (2010). Cultural-historical perspectives on teacher education and development. Learning teaching. Oxon, UK: Routledge.

Ellis, V. \& McNicholl, J. (2015). Transforming teacher education: Reconfiguring the academic work. London: Bloomsbury Academic.

Engeström, Y. (2007). Putting Vygotsky to work: The change laboratory as an application of double stimulation. In H. Daniels, M. Cole, \& J. V. Wertsch (Eds.), The Cambridge companion to Vygotsky (pp. 363-382). Cambridge: Cambridge University Press.

Engeström, Y. (2011). From design experiments to formative interventions. Theory \& Psychology, 21(5), 598-628. doi: http://dx.doi.org/10.1177/0959354311419252

Engeström, Y., Miettinen, R., \& Punamäki, R. (Eds.). (1999). Perspectives on activity theory. Cambridge: Cambridge University Press.

Eriksen, T. M., Hunskaar, T. S., \& Hyldmo, K. (2014). Fra praksisveiledere til lcrerutdannere. Evaluering av Universitetsskoleprosjektet [From practice mentors to teacher educators. Evaluation of the university school project]. Oslo: University of Oslo.

Furlong, J., Barton, L., Miles, S., Whiting, C., \& Whitty, G. (2000). Teacher education in transition: Re-forming teaching professionalism. Buckingham: Open University Press.

Grossman, P. L. (1990). The making of a teacher: Teacher knowledge and teacher education. New York: Teachers College Press.

Gundem, B. B. (1998). Understanding European didactics - An overview: Didactics (didaktik, didaktik(k), didactique). Oslo: Institute for Educational Research, University of Oslo.

Hamilton, D. (1999). The pedagogic paradox (or why no didactics in England?). Pedagogy, Culture and Society, 7(1), 135-152.

Henriksen, E., Angell, C., \& Tellefsen, C. W. (2015). Prosjekt Relekvant: Skreddersydde læringsressurser i fysikk, utviklet av forskere, lærere og lektorstudenter [Project ReleQuant: Tailor-made learning resources in physics developed by researchers, teachers, and student teachers]. In U. Rindal, A. Lund, \& R. Jakhelln (Eds.), Veier til fremragende 
lærerutdanning [Roads to excellence in teacher education] (pp. 45-56). Oslo: Universitetsforlaget.

Kennedy, M. (1990). A survey of recent literature on teachers' subject matter knowledge. Issue paper from the U.S. National Center for Research on Teacher Education, 90(3).

Klafki, W. (1998). Characteristics of critical-constructive didaktik. In B. B. Gundem \& S. Hopmann (Eds.), Didaktik and/or curriculum (pp. 307-330). New York: Peter Lang.

Knain, E. (2015). Scientific literacy for participation. A systemic functional approach to analysis of school science discourses. Rotterdam: Sense Publishers.

Latour, B. (1999). Pandora's hope. Essays on the reality of science studies. Cambridge, MA: Harvard University Press.

Lillejord, S. \& Børte, K. (2014). Partnerskap i lærerutdanningen: En forskningskartlegging [Partnerships in teacher education: An overview of research]. Oslo: Kunnskapssenter for utdanning.

Ludvigsen-utvalget. (2014). Elevens læering i fremtidens skole: et kunnskapsgrunnlag [Pupils' learning in the school of the future: Knowledge foundations]. Retrieved from http://blogg.regjeringen.no/fremtidensskole/files/2014/09/NOU201420140007000D DDPDFS.pdf

Ludvigsen-utvalget. (2015). Fremtidens skole. Fornyelse av fag og kompetanser [School of the future. Renewal of subjects and competences]. Retrieved from http://blogg.regjeringen.no/fremtidensskole/files/2015/06/NOU201520150008000D DDPDFS.pdf

Ludvigsen, S. (2015). Epilog: fagfornyelse, dybdelæring og progresjon i lærerutdanning [Epilogue: renewal of subjects, deep learning, and progression in teacher deucation]. In U. Rindal, A. Lund, \& R. Jakhelln (Eds.), Veier til fremragende lererutdanning [Roads to excellence in teacher education] (pp. 221-228). Oslo: Universitetsforlaget.

Lund, A. \& Engelien, K. L. (2015). Oppgaver og vurdering i digitale omgivelser [Tasks and assessment in digital environments]. In U. Rindal, A. Lund, \& R. Jakhelln (Eds.), Veier til fremragende lererutdanning [Roads to excellence in teacher education] (pp. 136-147). Oslo: Universitetsforlaget.

Lund, A., Furberg, A., Bakken, J., \& Engelien, K. (2014). What does professional digital competence mean in teacher education? Nordic Journal of Digital Literacy, 9(4), 281-299.

Lund, A. \& Hauge, T. E. (2011). Designs for teaching and learning in technology rich learning environments. Nordic Journal of Digital Literacy, 6(4), 258-271. Retrieved from http://www.idunn.no/ts/dk/2011/04/art04

Lund, A. \& Rasmussen, I. (2008). The right tool for the wrong task? Match and mismatch between first and second stimulus in double stimulation. International Journal of Computer-Supported Collaborative Learning, 3(4), 25-51.

Lødrup, V. \& Haugli, H. (2014, June 4). Å lede i en kunnskapseksplosion [To lead amidst an explosion of knowledge]. Finansavisen. Retrieved from http://abelia.no/ledelse/aa-lede-ien-kunnskapseksplosjon-article2964-129.html

Menter, I., Hulme, M., Murray, J., Campbell, A., Hextall, I., Jones, M., ... Wall, K. (2010). Teacher education research in the UK: The state of the art. Revue Suisse des sciences de l'education, 32(1), 121-142.

NOKUT. (2011). Vurdering av søknader om SFU - finalerunde [Evaluation of applicants for CETL (Centers of Excellence in Teaching and Learning) - finals]. Oslo: NOKUT.

Rindal, U., Lund, A., \& Jakhelln, R. (Eds.). (2015). Veier til fremragende løererutdanning [Roads to excellence in teacher education]. Oslo: Universitetsforlaget.

Rørnes, K. (2015). Universitetsskolen i lærerutdanningen: å koble praksis og teori i lærerutdanningen [University schools in teacher education: Linking theory with practice in teacher education]. In U. Rindal, A. Lund, \& R. Jakhelln (Eds.), Veier til fremragende 
lærerutdanning [Roads to excellence in teacher education] (pp. 75-86). Oslo: Universitetsforlaget.

Sannino, A. (2014). The emergence of transformative agency and double stimulation: Activity-based studies in the Vygotskian tradition. Learning, Culture, and Social Interaction, 4, 1-3. doi: http://dx.doi.org/10.1016/j.lcsi.2014.07.001

Sannino, A., Daniels, H., \& Gutiérrez, K. (Eds.). (2009). Learning and expanding with activity theory. New York: Cambridge University Press.

Schempp, P. G., Manross, D., Tan, S. K. S., \& Fincher, M. D. (1998). Subject expertise and teachers' knowledge. Journal of Teaching in Physical Education, 17, 342-356.

Shaffer, D. W. \& Clinton, K. A. (2006). Toolforthoughts: Reexamining thinking in the digital age. Mind, Culture, and Activity, 13(4), 283-300.

Shulman, L. S. (1986). Those who understand: Knowledge growth in teaching. Educational Researcher, 15, 4-21.

Shulman, L. S. (1987). Knowledge and teaching: Foundations of the new reform. Harvard Educational Review, 57, 1-22.

Sollid, H. \& Rindal, U. (2015). Hva vi mener om språk - sosiolingvistikk i norsk og engelsk [Our approach to language - sociolinguistics in Norwegian and English]. In U. Rindal, A. Lund, \& R. Jakhelln (Eds.), Veier til fremragende lærerutdanning [Roads to excellence in teacher education] (pp. 57-66). Oslo: Universitetsforlaget.

Vestøl, J. M., Jakhelln, R., \& Lund, A. (2015). Design av lærerutdanning [Designing for teacher education]. In U. Rindal, A. Lund, \& R. Jakhelln (Eds.), Veier til fremragende lærerutdanning [Roads to excellence in teacher education] (pp. 211-220). Oslo: Universitetsforlaget.

Vestøl, J. M. \& Lund, A. (in press). Co-configuring design elements and quality aspects in teacher education: A research agenda. In M. Peters, B. Cowie, \& I. Menter (Eds.), A companion to research in teacher education. Dordrecht: Springer.

Vygotsky, L. S. (1978). Mind in society: The development of higher psychological processes. Cambridge, MA: Harvard University Press.

Vygotsky, L. S. (1986). Thought and Language (A. Kozulin, Trans.). Cambridge, Ma: MIT Press.

\footnotetext{
${ }^{\mathrm{i}}$ We are aware that the terminology varies in this field. We followed Lillejord and Børte (2014) in their summary of research on partnerships, where they used "supervisor” and "mentor" to identify agents from universities and schools.
} 